\title{
The Optimal Gas Tax for California ${ }^{1}$
}

\author{
C.-Y. Cynthia Lin, Lea Prince \\ Department of Agricultural and Resource Economics \\ University of California, Davis, California
}

\begin{abstract}
This paper calculates the optimal gasoline tax for the state of California. According to our analysis, the optimal gasoline tax in California is $\$ 1.37$ gallon, which is over 3 times the current California tax when excluding sales taxes. The Pigovian tax is the largest part of this tax, comprising $\$ 0.85 /$ gallon. Of this, the congestion externality is taxed the most heavily, at $\$ 0.27$, followed by oil security, accident externalities, local air pollution, and finally global climate change. The other major component, a Ramsey tax, comprises a full $\$ 0.52$ of this tax, reflecting the efficiency in raising revenues from a tax on gasoline consumption due to the inelastic demand of this consumption good.
\end{abstract}

Keywords: gasoline tax; California

\footnotetext{
${ }^{1}$ Lin (corresponding author): Assistant Professor, Department of Agricultural and Resource Economics, University of California, Davis, One Shields Avenue, Davis, CA 95616; phone: (530) 752-0824; fax: (530) 752-5614; email: cclin@primal.ucdavis.edu. Prince: Graduate Student, Department of Agricultural and Resource Economics, University of California, Davis, CA; email: prince@primal.ucdavis.edu. We thank Paul Leiby, Ian Parry and James Wilen for helpful discussions. All errors are our own.
} 
With landmark legislation including the Global Warming Solutions Act of 2006 (AB 32) and air quality standards that are more stringent than those at the federal level, California is renowned for leadership nationally and internationally in implementing environmental regulation at the vanguard. To round out its portfolio, the state should consider policy to further curtail gasoline consumption and reduce vehicle miles traveled on California roads. Gasoline powered vehicles produce many negative externalities including air pollution, global climate change, accident and congestion costs, and dependence on foreign supplies of oil. While it has been argued that a gasoline tax is second-best as a corrective measure for each of these externalities separately (Parry and Small, 2005; Fullerton and West, 2003), it is perhaps the best policy to jointly address these due to the cost and difficulty of simultaneously implementing several first-best policies.

The debate over the "optimal" gasoline tax as an incentive policy is ongoing. In this paper, we use a Parry and Small $(2004 ; 2005)$ model for an optimal gasoline tax. Parry and Small (2005) calculated the optimal gasoline tax for the United States and the UK. We contribute by adjusting parameters from a national level to be specific to the state of California and by updating the model to account for the cost of oil dependence. ${ }^{2}$ An estimation of a California-specific gas tax is important for two main reasons. First, environmental policies in California set an example and pave the way for similar policies in other states and at the federal level. Second, California differs from the nation as a

\footnotetext{
${ }^{2}$ Parry and Small (2005) did not include this element based on previous research that showed the costs to be comparatively small. Based on recent studies showing significant demand sensitive energy security related costs to oil consumption which are not absorbed in market price, we feel that this component is necessary in determining the optimal gasoline tax and find the cost to be significant in our formulation.
} 
whole in several parameters including congestion, accidents, air quality, and environmental regulations, and therefore has a different optimal gas tax than the national gas tax estimated by Parry and Small (2005).

According to our analysis, the optimal gasoline tax in California is $\$ 1.37 /$ gallon, which is over 3 times the current California tax when excluding sales taxes. The Pigovian tax is the largest part of this tax, comprising $\$ 0.85 /$ gallon. Of this, the congestion externality is taxed the most heavily, at $\$ 0.27$, followed by oil security, accident externalities, local air pollution, and finally global climate change. The other major component, a Ramsey tax, comprises a full $\$ 0.52$ of this tax, reflecting the efficiency in raising revenues from a tax on gasoline consumption due to the inelastic demand of this consumption good. Because of the size of the Ramsey component, we see that the optimal tax is over $\$ 0.50$ higher than the marginal external cost. If we do not account for the Ramsey component, the gasoline tax would be $\$ 0.85 /$ gallon, the Pigovian gas tax, which is equal to the marginal external cost adjusted down to account for the narrow base of gasoline taxes relative to labor taxes.

The remainder of the paper is organized as follows. Section 1 provides a statistical description of California's passenger vehicle gasoline consumption and current gasoline tax. Section 2 addresses the primary objectives of raising the gasoline tax for California and arguments for a gasoline tax as a second-best policy. Section 3 lays out the analytical Parry and Small model and how it has been changed for this paper. Section 4 explains the parameter values chosen for our optimal gasoline tax estimation. Section 5 concludes. 


\section{California Data}

Figure 1 plots gasoline prices, sales and excise taxes in California over the years 1982-2006. ${ }^{3}$ Figure 2 shows vehicle miles traveled per day, California population and vehicle fuel economy data. Despite sometimes large fluctuations in gasoline prices, we see very little change in gasoline sales and vehicle miles traveled when we take population growth into account. This suggests that demand for gasoline is not very price responsive in the either the short or long run. The data plotted in figure 2 show that California vehicle miles traveled are growing at a significantly faster rate than population. Moreover, vehicle fuel economy has not improved and has actually decreased in recent years.

According to California Board of Equalization data, gasoline sales in California slipped in 2006 for the first time in 14 years. While California gasoline sales fell by 0.7 percent, Energy Department statistics showed more than a 1 percent increase in nationwide gasoline sales (SF Chronicle 2007a). This could indicate some sort of tipping point due to the recent upward trend in gasoline prices in addition to California's higher than average gasoline tax, indicating that - even with very inelastic demand - a gasoline tax could have the desired effect of reducing gasoline consumption in California.

Currently, California has the third highest total $\operatorname{tax}^{4}$ on gasoline (averaging 58.5 cents per gallon) following New York (60.8 cents per gallon) and Hawaii (60.4 cents per gallon). The nationwide average tax on gasoline is about 45.8 cents per gallon. In each

\footnotetext{
${ }^{3}$ The gas tax plotted excludes the sales tax.

${ }^{4}$ Figures include excise tax, state and local sales taxes, and other taxes
} 
state, the gasoline tax can be broken down into a federal excise tax of 18.4 cents per gallon, a state excise tax - averaging 18.2 cents per gallon across the country - and other taxes which include sales taxes, gross receipts taxes, oil inspection fees, underground storage tank fees, and other miscellaneous environmental fees (API 2007). California's state gasoline excise tax is currently 18 cents per gallon, and local and state sales taxes are levied on the price of fuel and excise taxes.

Figure 1: Gasoline Prices, Sales and Taxes in California

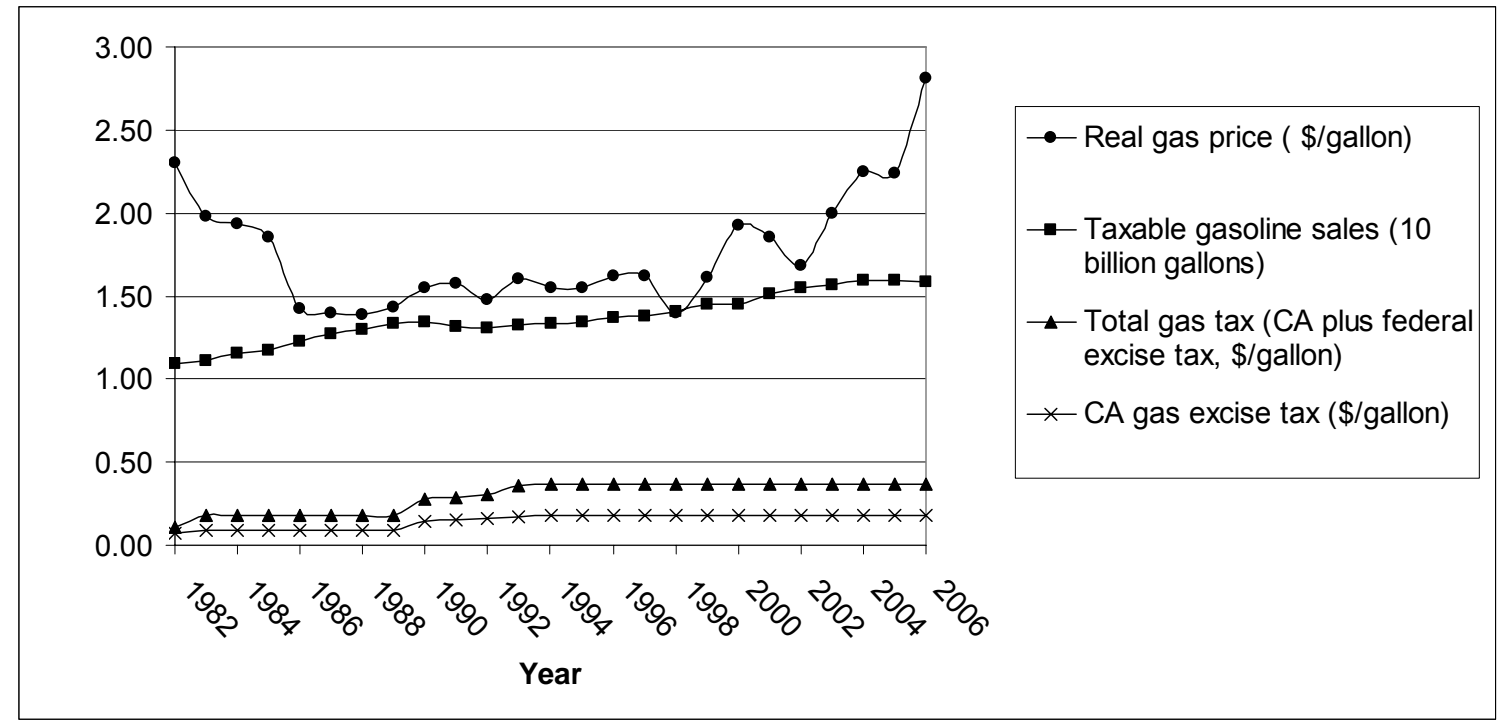

Data sources: California Energy Commission (gas price), California State Board of Equalization (gas sales), California Department of Transportation (CA gas tax).

Figure 2. Transportation Related Statistics for California

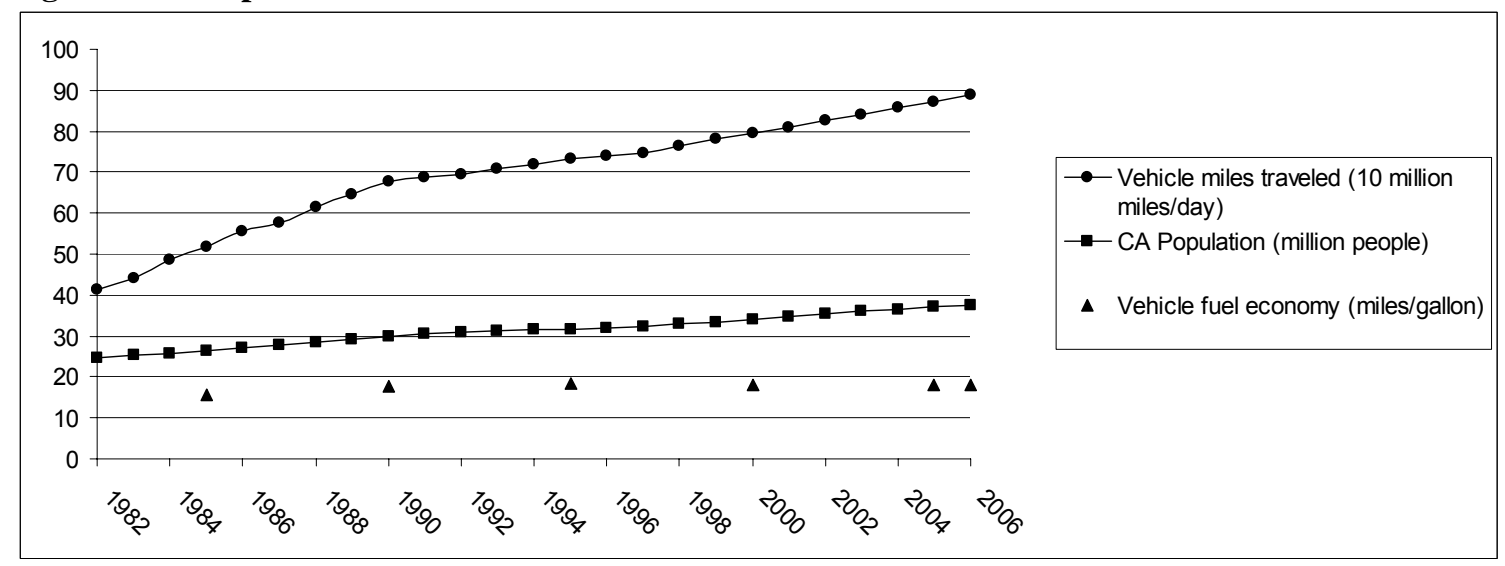

Data sources: California Air Resources Board (VMT and population), California Department of Transportation (fuel economy). 
California gasoline prices tend to be higher and more variable than in other states. This is largely in part due to California's reformulated gasoline program which has more stringent requirements on clean gasoline than the federal mandate. There are relatively few sources of reformulated gasoline outside of the state, meaning that California refineries tend to operate near full capacity. Volatility in prices occurs when multiple refineries experience down time, ${ }^{5}$ which leads to shortages of reformulated gasoline supply (EIA 2007).

\section{Raising the Gas Tax in California}

\subsection{Components of the Optimal Gasoline Tax for California}

In determining the optimal Pigovian tax on gasoline we have three objectives. The first objective is environmental protection, with particular regard to air pollution and global climate change. According to Mankiw (Mankiw 2006), who has proposed a raise in the gas tax, higher gasoline taxes are "the most direct and least invasive policy to address environmental concerns." Air pollution and global climate change are both critical environmental issues for California: California has an alarming 16 out of the 25 most ozone-polluted counties in the nation, including all of the top six, ${ }^{6}$ and is the world's 12th largest source of carbon dioxide. If greenhouse gases continue to increase, climate models predict that the average temperature at the Earth's surface could increase

\footnotetext{
${ }^{5}$ Refinery margins are higher due in large part to price volatility in the region.

${ }^{6}$ Source: American Lung Association State of the Air 2007 report. Negative effects of air pollution have been extensively documented, and include impairment of human lung function, degradation of materials, and injury to plants. In addition to adverse health effects, the high ambient ozone levels found in Southern California and the San Joaquin Valley also cause yield reductions up to $30 \%$ for some crops (Hall et al., 1992).
} 
from 3.2 to $7.2^{\circ} \mathrm{F}$ above 1990 levels by the end of this century (EPA, 2009). Locally in California, the consequences of global warming potentially include a $90 \%$ loss of California's Sierra snowpack (Nunez and Pavley, 2007). Such climate change could have adverse affects on human health and the environment.

So far, the most widely touted policy meant to reduce local air pollution and greenhouse gas emissions has been implementation of stricter CAFE standards. CAFE standards, however, are not entirely effective in controlling externalities from motor vehicles. For example, some argue that CAFE standards are partly responsible for growth of SUV's because they fall into the light truck category, which have less stringent standards than cars. CAFE standards may also lower the cost per mile of driving and therefore increase vehicle miles traveled and, hence, congestion. In contrast, higher gasoline taxes encourage development of more fuel-efficient vehicles, discourage people from buying and driving fuel inefficient vehicles, and discourage driving altogether. Moreover, in his analysis of the hypothetical transport demand in the whole OECD area for various tax scenarios, Sterner (2007) finds that gasoline taxes are the single most powerful climate policy instrument implemented to date. He finds that the atmospheric carbon content would have been $1 \mathrm{ppm}$ higher than it is today if gasoline taxes had not been used the way they have in Europe.

A second objective in determining the optimal Pigovian gasoline tax is the reduction of road congestion and traffic-related accidents. Congestion is a particularly acute problem in California. According to 2000 statistics from RAND, California's congestion costs due to delay and wasted fuel alone are 1.88 times higher than the 
national average. ${ }^{7}$ California's accident per capita rate is lower than that of the average for the entire United States, however, California still sees an accident fatality rate of over 3500 persons per year.

A third objective is to reduce dependence on foreign oil. A higher tax on gasoline would discourage oil consumption, reducing our dependence on fossil fuels, particularly oil imported from OPEC. In a recent study, Leiby (2007) defines three components that add to the market price to make up the full cost of petroleum imports: ${ }^{8}$ the cost of U.S. import demand and its (currently strong) effect on the world oil price and the market power retained by OPEC, the cost of the risk of sudden shortage in the supply of foreign oil, and the cost of active oil security policies. ${ }^{9}$ As explained in Section 4 , we use parameter values from Leiby's (2007) study, which include the costs of the first and second components, but not the third.

Apart from the necessity to account for the negative externalities from gasoline powered passenger vehicles, a tax can also provide government revenue. California net taxable gasoline sales between 2001 and 2006 averaged upwards of 15.5 billion gallons ${ }^{10}$ per year. A tax hike of even 10 cents per gallon would have the capacity to raise revenue of 1.5 billion dollars per year. It is important to note here that - if a gas tax is the preferred policy - there is still the question of how to deal with the tax revenue. This discussion is beyond the scope of this paper. We note, however that, if there are concerns

\footnotetext{
${ }^{7} \mathrm{http}: / /$ ca.rand.org/stats/statlist.html

${ }^{8}$ Leiby's calculation omits some costs including environmental costs, policy costs and spillover effects.

${ }^{9}$ Oil security policies might include military presence in unstable, oil-producing regions and the upkeep of the Strategic Petroleum Reserve.

${ }^{10}$ This figure includes aviation gasoline sales. Data are taken from California State Board of Equilization, Special Taxes Department Fuel Taxes Division.
} 
about the regressivity of a gasoline tax, tax revenue could be balanced out by reducing income taxes.

\subsubsection{Gasoline Tax as Second-Best Policy}

In the economics literature, a Pigovian tax on gasoline is generally considered a second best policy. For example, Parry and Small (2005) note that a tax on emissions would better internalize local air pollution, a tax on peak-period driving would better tackle the congestion problem, and a tax on vehicle miles traveled (VMT) would most effectively lower accident externalities. These first best policies can be infeasible, however, because they have a high cost of implementation and monitoring, and no single first-best policy is able to efficiently address all of the objectives discussed above.

\subsubsection{Some Notes on Tax Incidence}

It has been shown that gasoline tax incidence falls the most heavily on the middle to upper middle classes. A tax on gasoline is not regressive across the lowest incomes based on the fact that the fixed cost of owning a vehicle excludes lowest income families from the market (Fullerton and West, 2003). As far as producer/consumer incidence is concerned, consumer incidence is higher at the state level when there is greater elasticity of supply compared to the nation. This occurs when producers have the ability to sell gasoline across borders and in states that sell relatively smaller quantities of gasoline (Chouinard and Perloff, 2003). Because California requires the use of reformulated gasoline and because the relative sales in California are large when compared to a national average, we would expect a relatively lower consumer incidence. 


\section{A Model of the Optimal Gas Tax}

\subsection{Analytical framework for Parry and Small model}

In this section, we lay out the Parry and Small model (Parry and Small 2005) for an optimal gasoline tax and highlight our changes. The style and description in this section closely follows the presentation of Parry and Small (2005).

The representative agent in a closed economy model has the utility function:

$$
U=u(\Psi(C, M, T, G), N)-\varphi(P)-\delta(A)-\eta(O)
$$

The functions $u($.$) and \Psi($.$) are quasi-concave. \varphi(),., \delta($.$) and \eta($.$) are weakly convex$ functions representing disutility from pollution, accident risk, and oil dependence. All variables are in per capita terms and defined as follows:

C: quantity of numeraire consumption good

M: travel measured in vehicle miles

$\mathrm{T}$ : time spent driving ${ }^{11}$

G: government spending

$\mathrm{N}$ : leisure or non-market time

P: quantity of (local and global) pollution

\footnotetext{
${ }^{11}$ Time spent driving is included in the utility function to allow the opportunity cost of travel time to differ from the opportunity cost of work time
} 
A: severity-adjusted traffic accidents

O: oil dependence factors ${ }^{12}$

$G, P, O$ and $A$ are all characteristics of an individual's environment and are perceived as exogenous.

We modify the Parry and Small model by adding the disutility $\eta($.$) from oil$ dependence to the utility function.

Vehicle miles traveled (VMT) are produced according to the homogeneous function:

$$
M=M(F, H)
$$

where $\mathrm{F}$ is fuel consumption and $\mathrm{H}$ is money expenditure on driving.

This function allows for the tradeoff between vehicle cost and fuel efficiency while holding quality constant. It accounts for the fact that people will buy more fuelefficient cars in addition to driving less when gasoline prices or taxes increase.

Driving time is a function of VMT, the inverse of the average travel speed, $\pi$, and the fixed aggregate miles driven per capita, $\bar{M}$ :

$$
T=\pi M=\pi(\bar{M}) M
$$

\footnotetext{
${ }^{12}$ Oil dependence factors include military spending, etc.
} 
Because $\bar{M}$ is treated as fixed, $\pi$ will be fixed, implying that drivers do not take into account their own contribution to congestion. We can make the assumption that $\pi^{\prime}>0$, implying that an increase in VMT leads to more congested roads.

Pollution is made up of two types of pollution, $P_{F}$ and $P_{M}$, which differ by the types of externalities they cause. $P_{F}$ is a carbon dioxide type of pollutant, which depends directly on fuel consumption, and therefore causes the fuel-related pollution damages resulting from global climate change: $P_{F}(\bar{F})$, where $\bar{F}$ is aggregate fuel consumption per capita and $P_{F}^{\prime}>0$. In contrast, $P_{M}$ is a pollutant which depends only on miles driven, and therefore causes the distance-related pollution damage resulting from local air pollution: ${ }^{13} P_{M}(\bar{M})$, where $P_{M}^{\prime}>0$. Both costs of pollution from driving are borne by other agents, so those costs are ignored by the agent driving.

The number of accidents per capita is dependent on the amount of aggregate driving per capita and is exogenous to the individual agent:

$$
A=A(\bar{M})=a(\bar{M}) \bar{M}
$$

where $a(\bar{M})$ is the accident rate per mile. Internal costs of accidents such as the risk of an accident impacting an agent's decision about how much to drive, are taken to be implicit and included in either the utility function $\Psi($.$) , or money costs H$. Other costs are

\footnotetext{
${ }^{13}$ For example, nitrogen oxides, hydrocarbons, carbon monoxide - regulations force emissions per mile to be uniform across most new vehicles.
} 
external, ${ }^{14}$ and included in $\delta($.$) , where some of these costs are borne by other users of the$ roads such as pedestrians or cyclists or number of trips. So, disutility from accidents is taken to be independent of the amount of individual's own driving. ${ }^{15}$

Oil dependence is a function of aggregate fuel consumption:

$$
O=O(\bar{F})
$$

where $O^{\prime}(\bar{F})>0$. Like pollution, the costs of oil dependence are borne by other agents, so we make the assumption that these costs are ignored by the driver when making fuel consumption decisions.

On the production side, we assume that firms are competitive and produce all market goods with constant returns to scale. All producer prices and the gross wage rate are exogenously fixed, and normalized to unity, with the exception of gasoline price, $q_{F}$. There is a tax on gasoline, $t_{F}$, and a tax on labor, $t_{L}$.

The agent has a budget constraint:

$$
C+\left(q_{F}+t_{F}\right) F+H=I=\left(1-t_{L}\right) L
$$

where $I$ is disposable income and $L$ is labor supply.

The time constraint on labor, leisure, and driving is given by:

\footnotetext{
${ }^{14}$ Indirect effects on accident externalities via changes in vehicle size are ignored partly because direction of effect is uncertain.

${ }^{15}$ It has been argued that the best policy to address accident externalities is actually a premium on individual driver's vehicle miles traveled through their insurance policy (Edlin and Mandic, 2006) and that a gasoline demand model should include insurance rates.
} 


$$
L+N+T=\bar{L}
$$

where $\bar{L}$ is the agent's time endowment.

Government expenditures are financed by taxes. The government does not directly tax or regulate externalities, except as incorporated in the functions $\delta(),. M(),. \pi(),. P_{F}(),. P_{M}(),. O($.$) and a($.$) .$

The government has a budget constraint:

$$
t_{L} L+t_{F} F=G
$$

With government spending taken as exogenous, this relationship allows a tradeoff between gasoline and labor revenues.

\subsection{Optimal gasoline tax calculation}

The optimal gasoline tax is the one that maximizes utility. If we take the derivative of utility with respect to the gasoline tax and set this equal to zero, after some manipulation (see Parry \& Small 2004), the optimal gasoline tax can be calculated from a formula comprised of three components. The first, an adjusted Pigovian tax, will differ slightly form the marginal external cost of fuel use (MEC). The MEC is comprised of the marginal costs of carbon emissions and dependence on foreign oil - in dollars per VMT and the marginal costs of distance-related pollution costs, accidents and congestion - in dollars per mile. The latter are multiplied by miles per gallon and the portion of the gasoline demand elasticity due to changes in VMT. The Pigovian tax is the MEC adjusted by a factor of $(1 /(1+\mathrm{MEB}))$, where MEB is the welfare cost in the labor market 
from an incremental increase in the tax on labor divided by the marginal revenue. This adjustment accounts for the narrow base of gasoline taxes relative to labor taxes, and thus their inferiority in efficiently raising revenues.

The second component is a Ramsey tax. Ramsey (Ramsey 1927) proposed the idea that goods with more inelastic consumer demand should be taxed over those with more elastic demand to minimize deadweight loss and maximize government revenue. In this model, Parry and Small base the Ramsey component on the idea that, as vehicle travel becomes a stronger substitute for leisure, the consumer demand for gasoline becomes more inelastic than the compensated demand for leisure.

Third, the congestion feedback component represents the effect that reduced congestion would have on taxed labor supply. This component accounts for the fact that, although a gas tax is expected to decrease congestion through behavioral change leading to fewer vehicle miles traveled, there could be shifts back towards greater vehicle miles traveled as the opportunity cost of driving decreases. When congestion decreases, the full cost of driving decreases and we might see a shift from leisure towards travel, which would in turn increase congestion.

The formula for the optimal gasoline tax is as follows:

$$
t_{F}^{*}=\text { Adjusted Pigovian tax }+ \text { Ramsey tax }+ \text { Congestion feedback, }
$$

where

$$
\text { Adjusted Pigovian tax }=\frac{M E C_{F}}{1+M E B_{L}}
$$




$$
\text { Ramsey tax }=\frac{\left(1-\eta_{M I}\right) \varepsilon_{L L}^{c}}{\eta_{F F}} \frac{t_{L}\left(q_{F}+t_{F}\right)}{1-t_{L}}
$$

$$
\text { Congestion Feedback }=\frac{\beta M}{F} E^{C}\left\{\varepsilon_{L L}-\left(1-\eta_{M I}\right) \varepsilon_{L L}^{c}\right\} \frac{t_{L}}{1-t_{L}}
$$

and

$$
\begin{aligned}
& M E C_{F} \equiv E^{P_{F}}+E^{O}+(\beta M / F)\left(E^{C}+E^{A}+E^{P_{M}}\right) \\
& \beta \equiv \frac{d M / d t_{F}}{d F / d t_{F}} \frac{F}{M}=\frac{\eta_{M F}}{\eta_{F F}} \\
& M E B_{L} \equiv \frac{-t_{L} \frac{\partial L}{\partial t_{L}}}{L+t_{L} \frac{\partial L}{\partial t_{L}}}=\frac{\frac{t_{L}}{1-t_{L}} \varepsilon_{L L}}{1-\frac{t_{L}}{1-t_{L}} \varepsilon_{L L}}=\frac{t_{L} \varepsilon_{L L}}{1-t_{L}\left(1+\varepsilon_{L L}\right)} .
\end{aligned}
$$

$\eta_{F F}$ is the own price elasticity of demand and $\eta_{M F}$ reflects the portion of this that results from a shift in VMT. $\eta_{M I}$ is the elasticity of demand for VMT with respect to disposable income. $\varepsilon_{L L}^{c}$ and $\varepsilon_{L L}$ are the compensated and uncompensated labor supply elasticity, respectively.

\section{$4 \quad$ Results}

\subsection{Parameter Values}

Initial fuel efficiency: $M / F$

19.84 miles/gal 
To obtain an updated value for initial fuel efficiency for California, we use data from 1990 to 2005, which yield a weighted average of California statewide vehicle fuel economy of 19.84 miles per gallon (mpg) with a range of 18.4 to $20.19 \mathrm{mpg} .{ }^{16}$ Because of the nonlinear nature of fuel economy data, we average the data over several years rather than use the data for the most recent year available. ${ }^{17}$ Although one might expect average fuel economy to be continuously rising across time, the data show a decrease in fuel economy in recent years, due to a recent downturn in the average fuel economy of gasoline automobiles and passenger-type trucks, likely due to years of falling gasoline prices and low gasoline taxes. Figure 3 shows data points plotted at five year intervals for California's weighted average vehicle fuel economy and vehicle classifications. ${ }^{18}$

Figure 3. California Vehicle Fuel Economy

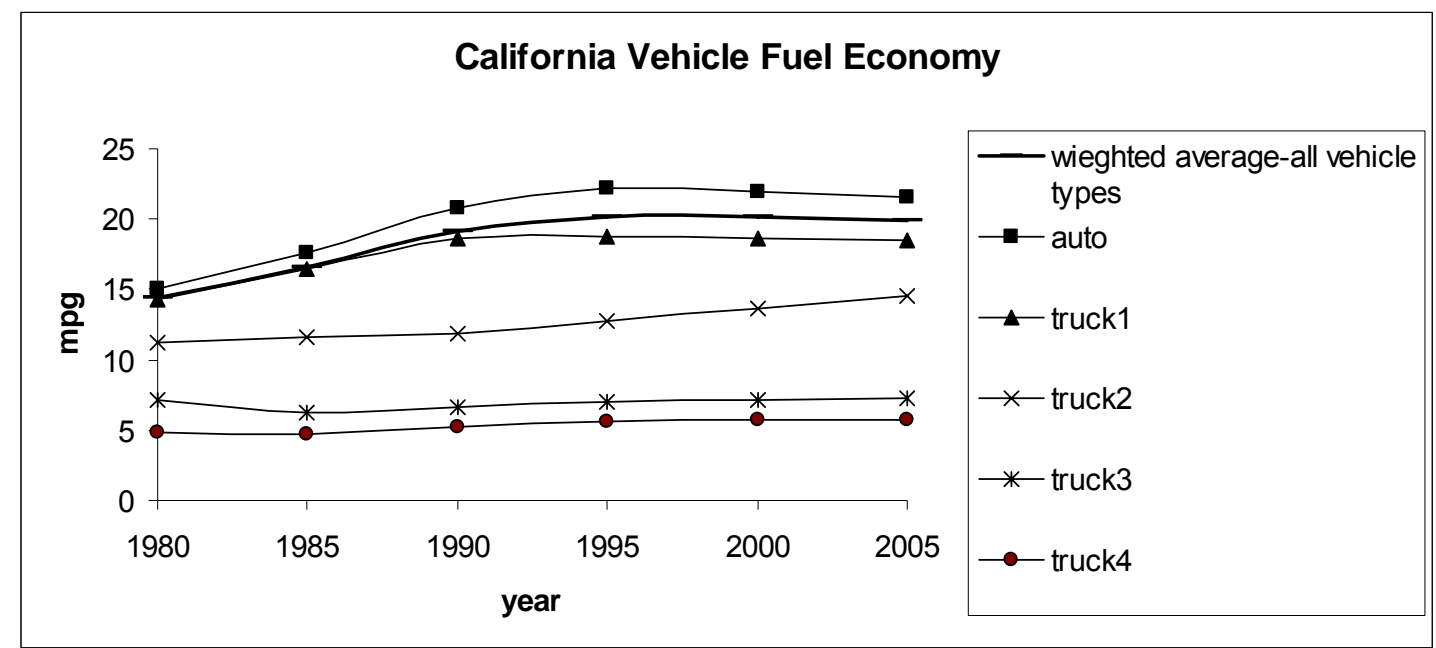

Data Sources: California Department of Transportation, California Motor Vehicle Stock, Travel and Fuel Forecast

Local air pollution damages (distance related): $E^{P_{M}}$

2.34 cents/mile

\footnotetext{
${ }^{16}$ Data are from California Department of Transportation and are for gasoline autos, 3 classes of trucks and motorcycles.

${ }^{17}$ Weighted average for 2005 is 19.94 , which is the most recent year available.

${ }^{18}$ Weights include all classes of trucks.
} 
The distance and fuel related pollution damages parameters are taken from Parry and Small's estimates of 2.9 cents per mile and 6 cents per gallon respectively, updated to 2006 prices. They represent the damages from local air pollution and global climate change, respectively. It should be noted here that these values are very rough estimates and Parry and Small make a point to emphasize the "great uncertainty" here. Further, the values that Parry and Small report are for the United States. We have not taken into account that California has the reformulated gasoline program which requires specially formulated gasoline meant to reduce emissions. Regardless, it is important to notice that the fuel related pollution damages are small in comparison to local pollution.

Cost of oil dependence: $E^{o}$

20.93 cents/gallon

The cost of oil dependence is estimated based on an Oak Ridge National Laboratories study by Paul Leiby (Leiby, 2007). Leiby ${ }^{19}$ estimates the incremental benefits to society, in dollars per barrel, of reducing U.S. imports of oil. His approach flushes out energy-security related, demand-sensitive costs that are not reflected in market prices. These costs include: (1) the higher costs for oil imports resulting from the effect of U.S. import demand on the world oil price and OPEC market power; and (2) the risk of dislocations of the domestic economy and reductions in U.S. economic output

\footnotetext{
${ }^{19}$ Leiby makes a strong argument that this estimate of the marginal economic benefit to society of a reduction in imports should not be used as a direct oil tax or import tariff and that a direct Pigovian tax will not efficiently address these market failures. (see Leiby, pg 30) It must be noted here that we do not disagree with Leiby's reasoning, however we are choosing to use his figure as the best estimate available to us for a marginal cost of oil dependence, which we feel should be accounted for in a gasoline tax. As noted, the optimal gas tax suggested in this paper is not meant as a direct policy recommendation, but a tool for policy makers.
} 
caused by sudden disruptions in the supply of imported oil to the U.S. Leiby's estimate does not include any costs for military programs, and the difficult-to-quantify foreign policy impact of oil import reliance. Moreover, it is not a measure of the full social costs of oil imports, or the full magnitude of the oil dependence and security problem. Rather, it is a measure of the quantifiable per-barrel economic costs that the U.S. could avoid by a small-to-moderate reduction in oil imports. Leiby estimates a range of marginal cost of oil dependence between $\$ 6.71$ and $\$ 23.25$ per barrel of oil (BBL), with a central value of \$13.58/BBL of imported oil (\$2004), which translates to approximately 20.93 cents/gallon of gasoline with a range of 10.34 to 35.83 cents/gallon in 2006 dollars. $^{20}$

External congestion cost: $E^{C}$

4.4 cents/mile

Using RAND data, we compared average congestion costs for major cities in California and the United States. We found that average congestions costs in 2000 were $65 \%$ higher in California than in the US. Taking this into consideration, we chose to use a central congestion cost value of 4.4 cents $/$ mile with a range of $1.5-9.0$ cents $/ \mathrm{mile}$.

External accident cost: $\quad E^{A}$ 2.83 cents/mile

US Census data show that CA accidents per capita in 2005 were $80 \%$ of the US total for 2000, when Parry and Small estimated marginal costs of accidents. Based on these data, we make adjustments to the Parry and Small accident cost and, after updating

20 This is divided by 42 gallons/barrel. While a barrel of oil produces about 19.5 gallons of gasoline, we divided by 42 because dividing by 19.5 would indicate that the other products produced from refining do not have a cost of oil dependence. Further, we multiplied this by 0.6 because this cost of oil dependence is only on imported oil. Rough estimates show that about $60 \%$ of U.S. oil is from foreign sources. The upper bound of our range allows for the possibility that the non-gasoline fractions may be easier to substitute, so that we should divide by less than 42 . 
to 2006 prices, we use a central value of 2.83 cents/mile with a range of 1.13 to 7.03 cents/mile. This is in line with recent studies, which put the marginal external costs at around 2 to 7 cents per mile (e.g., US Federal Highway Administration, 1997; Lindberg, 2001; Mayeres, Oschelen and Proost , 1996; Miller et al., 1998; Parry, 2004).

Gasoline price elasticity: $\eta_{F F}$

We estimate the optimal gas tax using an intermediate-run estimate of the gasoline price elasticity of demand and a range that incorporates values from our analysis and from the literature. Because the gasoline price elasticity plays a key role in the optimal gasoline tax formulation, the methodology by which we arrive at our central parameter value and the range is discussed in detail in section 4.2.

To determine the intermediate-run gas price elasticity in California, we estimate a simple double log model using California specific data over 37 years. Our estimate differs from previous studies because we include more recent data and because our data is specific to California, rather than for the whole United States. In particular, we include the years 2000 to 2007 in our study, which might account for the less elastic estimate for California demand than previous studies have found for the US using data which exclude these recent years.

Based on our estimates, we use a central value of price elasticity of demand for gasoline of -0.221 for an intermediate-run estimate, however we provide analysis over a broad range of elasticities, from -0.101 to -1.0 , so that policy makers might take note of the wide variation of the optimal tax as gas price elasticity varies and better understand 
the implications of a shift towards more inelastic demand. Although our central value is derived from a model that estimates a more intermediate-run elasticity, the range we use encompasses the range of mean long-run elasticities found in the literature. We further the analysis by calculating the optimal gas tax using a short-run elasticity that we estimate for California using a lagged endogenous model. An estimation using a short- to intermediate-run elasticity may be more relevant to policy aimed towards the Ramsey discussion and to shorter-run issues such as congestion, accidents and local air pollution. An intermediate- to long-run elasticity may be more relevant for issues of climate change and dependence on foreign oil. ${ }^{21}$

Elasticity of VMT with respect to consumer fuel price is estimated using California data for the years 1970 to 2007 . We use a value of -0.065 for an intermediaterun value and -0.074 for a short-run value. Regression results are shown in section 4.2, tables 6 and 7.

VMT portion of gas price electricity: $\beta \equiv \frac{\eta_{M F}}{\eta_{F F}}$

Based on dividing the elasticity of VMT by the elasticity of demand for gasoline with respect to consumer fuel price we estimate the VMT portion of gas price elasticity

\footnotetext{
${ }^{21}$ Dependence on foreign oil could be taken into consideration in both short and long term policy decisions. Immediate changes in demand for gasoline might affect the production decisions of oil producing countries while switching to alternative fuels as a means to free up dependence on oil is typically a policy option thought of in the longer run.
} 
for California to be 0.3. Parry and Small use an estimate of 0.4, based on their review of several studies from the 1990's . ${ }^{22}$

$\beta$ represents the portion of gasoline elasticity demand that is due to a change in vehicle miles traveled versus, for instance, increases in fuel economy. We use a range of 0.2 up to 1 , which would be the value if all of the response to higher gasoline prices was due to a change in vehicle miles traveled.

For the short-run analysis, we use a value of 0.7 , indicating that agents decrease their consumption of gasoline when prices rise largely by simply decreasing miles driven. The decrease is likely realized by a decrease in trips taken or a switch to carpooling or alternative forms of transportation. This is reasonable as it is likely much easier to change miles traveled in the short-run than change vehicle fuel efficiency. ${ }^{23}$

VMT expenditure elasticity: $\eta_{\mathrm{MI}}$

This component captures the elasticity of gasoline demand with respect to disposable income. Regressions using California data and a static model for intermediaterun analysis yield an estimate of 0.3. Our estimate based on the use of short-run elasticities is 0.07 , telling us that consumers respond less by changing miles driven to changes in income in the short run.

Uncompensated Labor Supply elasticity: $\varepsilon_{l l}$

${ }^{22}$ See Parry and Small (2004) footnote 44

${ }^{23}$ Although, it is possible to increase fuel economy through decreases in highway speed and acceleration rates, changing commute times to avoid congestion periods and vehicle maintenance such as proper tire pressure. 
We use the same parameter values for uncompensated and compensated labor supply elasticities as Parry and Small. Based on a large literature on labor supply elasticities, they chose central values of 0.2 and 0.35 for uncompensated and compensated labor supply elasticities respectively with ranges of 0.1 to 0.3 and 0.25 to 0.50. These elasticities are averaged across males and females and reflect decisions about work hours and participation.

Producer Price of Gasoline: $q_{f}$ 222.89 cents/gallon

Producer price of gasoline is an average of retail gasoline prices from January 2004 to December 2006 in real 2006 prices. ${ }^{24} \mathrm{We}$ use a range of 152.46 cents/gallon, which is based on a low of 2 standard deviations below the mean to 500 cents/gallon. ${ }^{25}$ The high range is in response to recent spikes in gasoline prices.

Initial tax rate on gasoline: $t_{f}^{0}$ 37.8 cents/gallon

The current tax on gasoline in California is $\$ 0.378$ per gallon. This is comprised of an 18.3 cents federal excise tax, 18 cent California excise tax and 1.5 cents in underground storage tank fees. We do not include the sales tax in this figure. The sales

\footnotetext{
${ }^{24}$ Data are from Energy Information Administration data. The data used were for California All Grades All Formulations Retail Gasoline prices and were converted to real 2006 prices.

${ }^{25} \mathrm{We}$ use an average over a range ending in December 2006, as this is the last data year used in our regression analysis for the elasticity calculations.
} 
tax is applied to goods in general and does not increase the price of gasoline relative to other goods. $^{26}$

\subsection{Gas Price Elasticity of Demand and VMT Calculations}

\section{Background and literature}

The estimation of demand models for gasoline has produced varying results over the past few decades and continues to be a subject of great interest. Estimates drawn from analysis that includes recent data and California-specific data are scarce, however. Table 1 displays results of 6 previous surveys of studies estimating the elasticity of demand for gasoline using data spread over the years 1929 to 2000, and one recent study (Hughes et al., 2008) estimating the short-run elasticity using more recent years of data. For the studies covering years ranging from 1929 to 2000, the mean short-run elasticity ranged from -0.25 to -0.28 and the mean long-run elasticity ranges from -0.64 to -0.86 . The remaining study, Hughes et al. (2008), shows that demand has become more inelastic over the recent years. In particular, they find that short-run elasticities have decreased by up to an order of magnitude from a range of -0.21 to -0.34 for the years 1975 to 1980 , to a range of -0.034 to -0.077 for the recent years 2001 to 2006 .

\footnotetext{
${ }^{26}$ This reasoning is based on comments in an email from Ian Parry responding to the authors' questions. He also noted that sales taxes are implicitly included in the overall tax burden on labor.
} 
Table 1

\begin{tabular}{|l|cc|cc|}
\hline \multicolumn{5}{|c|}{ Previous estimates of short-run (SR) and long-run (LR) elasticities of demand } \\
\cline { 2 - 5 } & \multicolumn{3}{|c|}{ SR } & \multicolumn{3}{c|}{ LR } \\
\cline { 2 - 5 } & mean & range & mean & range \\
Dahl and Sterner, 1991 & -0.26 & -0.22 to -0.31 & -0.86 & -0.80 to -1.01 \\
Goodwin, 1992 & & & & \\
$-\quad$ Time series & -0.27 & & -0.71 & \\
$-\quad$ Cross Section & -0.28 & & -0.84 & \\
Goodwin et al., 2004 & -0.25 & -0.01 to -0.57 & -0.64 & 0 to -1.81 \\
Graham and Gleister, 2002 & & -0.2 to -0.5 & & -0.23 to -0.8 \\
Graham and Gleister, 2004 & -0.25 & 0.59 to -2.13 & -0.77 & 0.85 to -22.0 \\
Hanley et al., 2002 & -0.25 & -0.01 to -0.57 & -0.64 & 0 to -1.81 \\
Hughes et al., 2008 & & & & \\
$-1975-1980$ & & -0.21 to -0.34 & & \\
$-2001-2006$ & & -0.034 to -0.077 & & \\
\hline
\end{tabular}

Davis and Killian (2009) argue that tax changes are more persistent than typical price changes, and find the elasticity of demand with respect to changes in tax to be -0.16 using national aggregate data, -0.32 using state panel data, and between 0.03 and -0.17 using a structural vector autoregression model, using recent data from 1989 to 2007 or to 2008 depending on the model. Thus, even though they suggest that a longer-run elasticity may be appropriate for evaluating gas taxes, their estimates of the tax elasticity are more in the range of previous estimates of the short-run price elasticity than the more elastic previous estimates of the long-run price elasticity, perhaps because they are using more recent data, when demand has become more inelastic.

\section{Basic model}

To estimate gasoline price elasticity, we start with a basic double log model.

$$
\ln D_{t}=\beta_{0}+\beta_{1} \ln P_{t}+\beta_{2} \ln Y_{t}+\varepsilon_{t}
$$


where $D_{t}$ is per capita gasoline demand in gallons for year $t,{ }^{27} P_{t}$ is the real price of gasoline in 2008 constant dollars in year $t, Y_{t}$ is real per capita disposable income in 2008 constant dollars in year $t$, and $\varepsilon_{t}$ is a mean zero error term. Table 2 shows regression results using this basic double log model. Because of data limitations, the majority of this analysis is carried out using annual time series. Table 2 includes results using monthly time series as well for a robustness check.

The interpretation of the coefficients of the static model are not entirely clear. We would expect that the long-run elasticities are:

$$
\frac{\partial \ln D_{t}}{\partial \ln P_{t}}=\beta_{1} \quad \text { and } \quad \frac{\partial \ln D_{t}}{\partial \ln Y_{t}}=\beta_{2}
$$

Studies have shown, however, that some dynamic models tend to produce higher long-run elasticities than static models, indicating that the static model is actually an intermediate-run elasticity. We see further evidence below in the partial adjustment model that the elasticities from our static model are likely more reflective of those in the intermediate run.

\footnotetext{
${ }^{27}$ Gasoline demand is calculated as per capita vehicle miles traveled/vehicle fuel efficiency. For use of this model with monthly time series, we would simply incorporate another subscript to the variables, e.g. $\mathrm{Y}_{\mathrm{jt}}$ would be income in year t, month $\mathrm{j}$, and a month fixed effects term, $\varepsilon_{j t}$
} 
Table 2

OLS double log model for CA: 1970 - 2007

dependent variable: log of gasoline demand in CA

\begin{tabular}{lcc}
\hline \hline time series & annual & monthly \\
In P & -0.101 & -0.091 \\
& $(0.025)^{* * *}$ & $(0.007)^{* * *}$ \\
In Y & 0.307 & 0.304 \\
& $(0.024)^{* * *}$ & $(0.007)^{* * *}$ \\
Constant & -3.175 & -3.201 \\
& $(0.343)^{* * *}$ & $(0.101)^{* * *}$ \\
\hline Observations & 25 & 300 \\
R-squared & 0.91 & 0.90 \\
\hline \hline Robust standard errors in parentheses & \\
*** significant at 1\% & \\
The monthly model includes month fixed effects
\end{tabular}

Time Series Properties of Data

In a test for stationarity of the vector of variables in our model using an Augmented Dickey-Fuller (ADF) test, all of the variables were found to be integrated of the same order. Given this, we can view our model as a co-integration model such that our parameters will be consistent if our residuals are stationary (Engle and Granger 1987). ADF tests suggest stationarity of the residuals, thus we continue our analysis under the assumption of consistent parameters.

Partial Adjustment Model 
To account for the fact that adaptation to changes in gas price or income might not take place instantaneously, we can use a partial adjustment $\operatorname{mode}{ }^{28}$ which allows demand in the current period to depend on demand in an earlier period as well as income and gasoline price:

$$
\ln D_{t}=\varphi_{0}+\varphi_{1} \ln P_{t}+\varphi_{2} \ln Y_{t}+\varphi_{3} D_{t-1}+\varepsilon_{t}
$$

When we estimate equation (16) using OLS, $\varphi_{1}$ and $\varphi_{2}$ can be interpreted as the short-run price and income elasticities respectively. The elasticities, when fully adjusted to the equilibrium level, are $\varphi_{1,2} /\left(1-\varphi_{3}\right)$ and are typically interpreted as the long-run elasticities. However, when the speed of adjustment is relatively short, the fully adjusted elasticities may also be interpreted as short-run or intermediate-run data. Table 3 shows the partial adjustment model results. We find a short-run elasticity to be of the order of those estimated by Hughes et. al (2008) with an implied adjusted price elasticity of close to -0.1 , which is the elasticity estimated in our static model. ${ }^{29}$ The adjustment period is just over 2 years, which would lead us to believe that the static model produces an intermediate-run elasticity. Based on the gasoline demand elasticity literature, we expect long-run elasticity to be higher, and we account for this in the range that we use in our optimal gasoline tax formulation.

\footnotetext{
${ }^{28}$ Our discussion on the partial adjustment model follows the reasoning presented in Hughes et. al (2008).

${ }^{29}$ Partial adjustment model estimates using a monthly time series produce similar results.
} 
Table 3

Partial Adjustment Model for CA: $1970-2007$

\begin{tabular}{|c|c|c|c|}
\hline \multirow{2}{*}{$\begin{array}{l}\text { dependent variable: } \\
\text { lag length }\end{array}$} & \multicolumn{3}{|c|}{ log of CA demand } \\
\hline & no lag & 1 year & 2 years \\
\hline \multirow[t]{2}{*}{$\ln \mathrm{P}$} & -0.101 & -0.041 & -0.063 \\
\hline & $(0.025)^{\star * *}$ & $(0.018)^{* *}$ & $(0.030)^{* *}$ \\
\hline \multirow[t]{2}{*}{$\ln Y$} & 0.307 & 0.088 & 0.214 \\
\hline & $(0.024)^{* * *}$ & $(0.073)$ & $(0.060)^{* * *}$ \\
\hline \multirow[t]{2}{*}{$\ln \mathrm{D}(\mathrm{t}-1)$} & & 0.571 & 0.175 \\
\hline & & $(0.194)^{* * *}$ & $(0.131)$ \\
\hline \multirow[t]{2}{*}{ Constant } & -3.175 & -0.857 & -2.258 \\
\hline & $(0.343)^{\star * *}$ & $(0.847)$ & $(0.674)^{\star * *}$ \\
\hline Observations & 25 & 24 & 23 \\
\hline R-squared & 0.91 & 0.92 & 0.86 \\
\hline fully adjusted In P & & -0.096 & -0.076 \\
\hline fully adjusted In $Y$ & & 0.205 & 0.259 \\
\hline speed of adjustment in months (1/k) & & 28 & 29 \\
\hline \multicolumn{4}{|c|}{$\begin{array}{l}\text { Robust standard errors in parentheses } \\
{ }^{*} \text { significant at } 10 \% ;{ }^{* *} \text { significant at } 5 \% ;{ }^{* * *} \text { significant at } 1 \% \\
\text { note: for no lag regressions only, mean price over previous } 12 \text { months } \\
\text { was used as } \mathrm{P} \text { and results are based on OLS -- not IV -- regressions, so } \\
\text { they are slightly different than the intermediate values reported in table } 8 \\
\text { below. }\end{array}$} \\
\hline
\end{tabular}

\section{Identification issues}

To address the possible endogeneity of gas price in our model, we can look for instrumental variables to use in our analysis. Ideally, we want an instrument that is correlated with the price of gasoline, but uncorrelated with unobserved gasoline demand shocks. In the past, studies have often used refinery products as instruments (Ramsey, Rasche and Allen 1975; Dahl 1979). The validity of this instrument is arguable, however, because there is almost surely some correlation between prices of other refinery products and gasoline demand shocks. Hughes et al. (2008) try using oil production disruptions as instrumental variables between the years 2000 and 2005. They find in the first stage that 2 of the 3 disruptions noted are not significant. Instrumenting for only the third, they find that the gas price elasticity is significantly different and more elastic than the base model, 
however they note that these effects "may be small relative to other factors affecting price elasticity".

In light of the difficulty of finding an appropriate instrument for gasoline price, we try using US distillate fuel prices as an instrument and experiment with a few unique instruments -- gasoline prices in different US states and indices of industrial production (IP) in different countries. We show results using real Ohio gas prices and IP in India as an instruments. ${ }^{30} \mathrm{We}$ find significance in first stage regressions for all of the instruments, however, for both US distillate fuel prices and Ohio real gas prices, a Wu-Hausman test for endogeneity tells us that we cannot reject the hypothesis that gas price is exogenous. In this case, the endogenous regressor's effects on the estimates are not particularly meaningful, so instrumental variables (IV) estimates will not differ much from our OLS results. We find a higher F statistic from a Wu-Hausman test when we use Industrial Production in India (IP India) as an instrument. Thus, our IV estimation from this point relies on the use of IP India as an instrumental variable.

Tables 4 and 5 show first and second stage instrumental variable results ${ }^{31}$ with a range of instruments. When we use (IP India) as an instrument, we see a higher elasticity of demand to gas prices, indicating that unobserved variables cause a downward bias (in absolute value) in the OLS coefficient, which is consistent with results found in other IV analysis. Again, because of the limited data available to us for this analysis and the

\footnotetext{
${ }^{30} \mathrm{We}$ use gas prices in other states as an instrument based on the assumption that unobserved shocks to gasoline prices in California are specific to the state. Ohio was chosen semi-randomly, after eliminating states that directly supply oil, gasoline or petroleum products to California consumers or refineries. We looked at IP for India and China as they are countries where we believe that Industrial Production leads to enough demand for oil that it impacts world oil prices, which are correlated with California gasoline prices. We did not find a high enough correlation for China (based on fewer years of data), but we did find a high correlation for India.

${ }^{31}$ Using generalized method of moments (GMM) operator which is an efficient estimator.
} 
limited proof that India IP is, in fact, not a weak instrument, we use these estimates only

to help us establish a range of elasticities to use in the analysis.

Table 4

First Stage 2SLS for CA: 1970 - 2007^

dependent variable: log of CA real gas price (average over past 12 months)

\begin{tabular}{lcccc}
\hline \hline In Y & 0.052 & 0.176 & 0.071 & -0.722 \\
& $(0.070)$ & $(0.070)^{* *}$ & $(0.790)$ & $(0.722)$ \\
In US distillate price & 0.717 & & 0.603 & \\
& $(0.050)^{\star * *}$ & & $(0.319)^{*}$ & \\
In OH real gas price & & 0.799 & 0.129 & \\
& & $(0.060)^{\star * *}$ & $(0.359)$ & 0.014 \\
IP India & & & & $(0.004)^{* * *}$ \\
& & & & 11.965 \\
Constant & 0.898 & -0.952 & 0.592 & $(8.111)$ \\
& $(0.670)$ & $(0.775)$ & $(1.186)$ & 0.012 \\
F statistic (P value) & 0.000 & 0.000 & 0.000 & 0.89 \\
R-squared & 0.90 & 0.89 & 0.90 &
\end{tabular}

Robust standard errors in parentheses

${ }^{*}$ significant at $10 \%$; ${ }^{* *}$ significant at $5 \%$; ${ }^{* * *}$ significant at $1 \%$

^note: India IP data only available after 1994

Table 5

IV GMM for CA: 1970 - 2007^

dependent variable: log of CA demand

\begin{tabular}{|c|c|c|c|c|}
\hline $\ln P$ & $\begin{array}{c}-0.100 \\
(0.027)^{\star * *}\end{array}$ & $\begin{array}{c}-0.106 \\
(0.028)^{\star * *}\end{array}$ & $\begin{array}{c}-0.083 \\
(0.025)^{\star * *}\end{array}$ & $\begin{array}{c}-0.221 \\
(0.097)^{\star *}\end{array}$ \\
\hline $\ln Y$ & $\begin{array}{c}0.307 \\
(0.022)^{\star * *}\end{array}$ & $\begin{array}{c}0.308 \\
(0.022)^{\star * *}\end{array}$ & $\begin{array}{c}0.318 \\
(0.022)^{\star * *}\end{array}$ & $\begin{array}{c}0.512 \\
(0.166)^{* * *}\end{array}$ \\
\hline Constant & $\begin{array}{c}-3.177 \\
(0.327)^{\star \star *}\end{array}$ & $\begin{array}{c}-3.161 \\
(0.324)^{\star \star *}\end{array}$ & $\begin{array}{c}-3.390 \\
(0.301)^{\star * *}\end{array}$ & $\begin{array}{c}-5.005 \\
(1.522)^{\star * *}\end{array}$ \\
\hline Instruments used: & & & & \\
\hline In US distillate price & yes & & yes & \\
\hline $\begin{array}{l}\text { In OH real gas price } \\
\text { IP India }\end{array}$ & & yes & yes & yes \\
\hline Wu-Hausman F test (P value) & 0.907 & 0.470 & 0.979 & 0.010 \\
\hline Hansen J Statistic (P value) & - & - & 0.091 & - \\
\hline
\end{tabular}

Robust standard errors in parentheses

** significant at $5 \%$; ${ }^{* * *}$ significant at $1 \%$

${ }^{\wedge}$ note: India IP data only available after 1994 
Table 6 reports the VMT elasticity for California for OLS and IV models. The use of instruments does not have a large impact on the magnitude of VMT elasticity or income elasticity. Table 7 shows a range of gasoline demand and VMT elasticities using both OLS and IV estimation for annual and monthly time series, and gives intermediate- and short-run estimates. This table is useful in providing a range of VMT elasticity as a portion of demand elasticity, $\beta$.

Table 6

VMT elasticity for CA: 1970 - 2007^

Dependent Variable: log of VMT per capita

\begin{tabular}{lcc}
\hline \hline & OLS & IV GMM \\
\cline { 2 - 3 } In P & -0.068 & -0.065 \\
& $(0.026)^{* *}$ & $(0.055)$ \\
In Y & 0.291 & 0.328 \\
& $(0.030)^{* * *}$ & $(0.097)^{* * *}$ \\
Constant & 0.071 & -0.38 \\
& $(0.292)$ & $(0.892)$ \\
Instruments used: & & \\
IP India & & yes \\
\hline R-squared & 0.88 & 0.012 \\
F test first stage (P value) & & 0.099 \\
Wu-Hausman F test (P value) & \\
\hline \hline Robust standard errors in parentheses \\
* significant at 10\%; ** significant at 5\%; ${ }^{* * *}$ significant at $1 \%$ \\
^note: India IPP data only available after 1994
\end{tabular}

Table 7

\begin{tabular}{|c|c|c|c|c|c|}
\hline model & $\begin{array}{l}\text { method of } \\
\text { estimation }\end{array}$ & $\begin{array}{l}\text { elasticity of } \\
\text { demand }\end{array}$ & elasticity of VMT & $\begin{array}{c}\beta \text { (VMT portion of } \\
\text { elasticity) }\end{array}$ & time series ${ }^{\wedge}$ \\
\hline \multirow[t]{4}{*}{ static (intermediate-run) } & OLS & $-0.101^{* * *}$ & $-0.059^{* *}$ & 0.58 & (a) \\
\hline & & $-0.091^{* * *}$ & $-0.061^{* * *}$ & 0.67 & (m) \\
\hline & IV GMM & $-0.221^{* * *}$ & -0.065 & 0.29 & (a) \\
\hline & & $-0.226^{* * *}$ & $-0.074^{* * *}$ & 0.33 & (m) \\
\hline \multirow[t]{4}{*}{ dynamic (short-run) } & OLS & $-0.041^{* *}$ & -0.012 & 0.29 & (a) \\
\hline & & $-0.033^{* * *}$ & -0.003 & 0.09 & (m) \\
\hline & IV GMM & $-0.098^{* * *}$ & $-0.074^{* * *}$ & 0.76 & (a) \\
\hline & & $-0.166^{* * *}$ & $-0.111^{* * *}$ & 0.67 & (m) \\
\hline
\end{tabular}

* significant at $10 \% ;{ }^{* *}$ significant at $5 \% ;{ }^{* * *}$ significant at $1 \%$

$\wedge(a)$ annual dataset for years $1970-2007,(\mathrm{~m})$ monthly dataset for years $1982-2008$ 


\subsection{The Optimal Gasoline Tax}

Table 8 summarizes the parameter values used in our optimal gasoline tax formulation and their ranges. Using all low and high parameter values, respectively, we calculated a range for the California optimal gasoline tax to be 21 cents to 10 dollars with an mid-range value of $\$ 1.37$. This mid-range value is based on our intermediate-run gasoline price and VMT elasticities. When we calculate the optimal gas tax for the midrange values using short-run gasoline price and VMT elasticities - shown in parenthesis in table 8 - we find that the optimal gasoline tax for California is $\$ 3.23 .^{32}$ We see an increase in the adjusted Pigovian tax, due to the increased VMT portion of elasticity ${ }^{33}$ as well as an increase in the Ramsey tax, due to the fact that consumers are more inelastic in the short-run. These differences can be seen in Table 9 .

The far right columns in table 8 show how each parameter individually affects the formulation. By shifting any one parameter we get a range for the optimal gas tax between $\$ 0.79$ and $\$ 2.13$. The gasoline price elasticity has the greatest effect on the tax. If we leave the gasoline price elasticity at the mid-range value of -0.221 and shift the other parameters individually, we get a range for the optimal gasoline tax between $\$ 0.79$ and $\$ 1.95$. In any case, all of these values exceed the current gasoline tax for California.

\footnotetext{
${ }^{32}$ This is calculated using the annual dataset and the IV GMM results from table 7. If we use the OLS values for short-run elasticities in the optimal tax calculation, we estimate that the optimal tax is just shy of $\$ 5.00 /$ gallon.

${ }^{33}$ In the short-run, the behavioral change due to a gasoline tax is likely to be realized more with a decrease in vehicle miles traveled rather than through changes in efficiency.
} 
Table 9 shows the breakdown of the individual components of the tax using both short- and intermediate-run elasticity estimates and compares our calculation for California to Parry and Small's (P\&S) optimal gasoline tax calculation for the U.S.

Table 8

\begin{tabular}{|c|c|c|c|c|c|}
\hline \multicolumn{6}{|c|}{ Parameter Values and Optimal Gas Tax (2006 prices) } \\
\hline \multirow[b]{2}{*}{ Parameter } & \multicolumn{3}{|c|}{ Parameter Values $^{\wedge}$} & \multicolumn{2}{|c|}{$\begin{array}{c}\text { Gas Tax Using Low } \\
\text { and High Range } \\
\text { Values, ceteris } \\
\text { paribus }\end{array}$} \\
\hline & Mid-Range & Low & High & Low & High \\
\hline Initial fuel efficiency (miles/gallon): & 19.84 & 18.4 & 20.19 & 1.25 & 1.31 \\
\hline Pollution damages, local air pollution (cents/mile): & 2.34 & 0.47 & 11.72 & 1.17 & 1.95 \\
\hline Pollution damages, global climate change (cents/gallon): & 7.03 & 0.23 & 28.13 & 1.22 & 1.53 \\
\hline External congestion cost (cents/mile): & 4.4 & 1.5 & 9 & 1.16 & 1.68 \\
\hline External accident cost (cents/mile): & 2.83 & 1.13 & 7.03 & 1.18 & 1.59 \\
\hline Cost of oil dependence (cents/gallon): & 20.93 & 10.34 & 35.83 & 1.17 & 1.46 \\
\hline Gasoline Price Elasticity: & $-.22(-.098)$ & -1.0 & -0.101 & 1.07 & 2.13 \\
\hline Elasticity of VMT w.r.t. consumer fuel price: & $-0.065(-0.074)$ & -0.2 & -0.061 & 1.30 & 1.31 \\
\hline VMT portion of gas price elasticity: & $0.3(0.76)$ & 0.2 & 0.6 & 0.79 & 1.07 \\
\hline VMT expenditure elasticity: & $0.3(.07)$ & 1 & 0.2 & 1.25 & 1.39 \\
\hline Uncompensated labor supply elasticity: & 0.2 & 0.3 & 0.1 & 1.30 & 1.32 \\
\hline Compensated labor supply elasticity: & 0.35 & 0.25 & 0.5 & 1.15 & 1.57 \\
\hline Producer price of gasoline (cents/gallon): & 222.89 & 152.46 & 500 & 1.18 & 1.81 \\
\hline Government spending (USD): & 119.6 billion & - & - & & \\
\hline Taxable gasoline sales (USD): & 15.8 million & - & - & & \\
\hline Labor income (USD): & 958.1 billion & - & - & & \\
\hline Initial tax rate on gasoline (cents/gallon): & 37.8 & - & - & & \\
\hline Optimal Gas Tax & $1.37(3.85)$ & 0.20 & 10.00 & & \\
\hline
\end{tabular}


Table 9

\begin{tabular}{|l|c|c|c|}
\hline \multicolumn{3}{|c|}{ Optimal Tax Components } \\
\hline \hline & \multicolumn{2}{|c|}{ CA } & US (P\&S) \\
& $\begin{array}{c}\text { intermediate- } \\
\text { run }\end{array}$ & $\begin{array}{c}\text { short- } \\
\text { run }\end{array}$ & \\
\cline { 2 - 4 } Elasticity & -0.22 & -0.098 & -0.55 \\
VMT portion of gas price elasticity & 0.30 & 0.76 & 0.40 \\
Adjusted Pigovian Tax & 0.85 & 1.70 & 0.74 \\
Pollution -- fuel (global climate change) & 0.07 & 0.07 & 0.05 \\
Pollution -- distance (local air pollution) & 0.15 & 0.36 & 0.16 \\
Congestion & 0.27 & 0.67 & 0.29 \\
Accident & 0.18 & 0.43 & 0.24 \\
Oil Dependence & 0.21 & 0.21 & 0.00 \\
Ramsey Tax & 0.52 & 2.15 & 0.26 \\
Congestion Feedback Tax & 0.00 & 0.00 & 0.01 \\
\hline Total tax & $\mathbf{1 . 3 7}$ & $\mathbf{3 . 8 5}$ & $\mathbf{1 . 0 1}$ \\
\hline
\end{tabular}

\section{Concluding Remarks}

In California, fuel prices and excise taxes have been in the news for some time and a significant increase in the gasoline tax at the state and national levels is not a new idea. California already has one of the highest gasoline taxes in the country and California gasoline prices tend to be higher and more variable than in other states. Because taxes of any type are such a contentious issue and fuel taxes even more so, history has proven thus far that a gasoline tax would be something very difficult to get through the Californian political system. For example there is significant controversy over current gasoline tax revenues, ${ }^{34}$ new policy action, ${ }^{35}$ and tax incidence. ${ }^{36}$

\footnotetext{
${ }^{34}$ Revenue from state sales tax on gasoline is supposed to go for transportation projects under Proposition 42, which voters approved in 2002. But, in recent years, special provisions have been invoked by legislators and the governor, which have allowed close to $\$ 2.5$ billion to pay for other expenses. (SF Gate, 2006)
} 
Perhaps the most important consideration should be that of the inelastic demand for gasoline in California. Our presentation of gasoline demand elasticity with respect to price estimates for California should at the very least call attention to the fact that policy should be updated to reflect the current state in California. With highly inelastic gasoline demand, any incentive policy would have to induce a large shock to prices to induce a behavioral change. We focus on what we estimate to be an intermediate-run elasticity (adjusting from the short-run in approximately 2 years); however, we calculate the optimal gas tax over a broad range of elasticities so that policy makers with time varying objectives can better understand how a gas tax might change consumer behavior. For example, if the objective is to curb gasoline consumption in the very short run, a gasoline tax should be quite high - in fact, we estimate the optimal gasoline tax based on short-run consumer price elasticity of demand for gasoline to be $\$ 3.23$. On the other hand, if the objective is to incentify changes over a longer period of time, a lower tax would be appropriate. Based on our analysis, it is likely that - even in the long run - any tax on gasoline meant to address the objectives discussed above for the state of California should be higher than that which is currently in place.

We've calculated the optimal gasoline tax for California, based on intermediaterun gas price elasticity of demand to be $\$ 1.37$, with a full $\$ 0.52$ comprised of the Ramsey

\footnotetext{
${ }^{35}$ California has considered a tax-by-the mile scheme, where GPS devices would be installed in cars to keep track of their mileage and the tax would be paid at the pump. A computer inside the gas pump would communicate with the car to calculate the tax. This idea is meant to counterbalance the loss of tax revenues - which fund road repairs and highway projects -- with more fuel efficient cars on the road. The system could also be used to internalize congestion externalities by charging higher fees for rush-hour driving (CBS, 2005)

${ }^{36}$ Assemblywoman Audra Strickland, R-Moorpark, authored AB 2621 - a bill seeking to eliminate the sales tax on gas. She estimated that eliminating the sales tax would translate to $\sim \$ 300$ to $\$ 400$ extra in savings per year per household. (SF Gate, 2006)
} 
component, which takes into consideration the government's ability to raise revenue on a good with highly inelastic demand. Revenue raised on a gasoline tax could be used to offset income taxes to address regressivity or to fund research into new and alternative energy sources. If we were only interested in the adjusted Pigovian component of this tax, meant to simply "internalize" the externalities caused by gasoline consumption in California the optimal tax would be $\$ 0.85 /$ gallon, which is more than 3 times the current tax excise tax and more than twice the total tax. When we break this down by specific externalities, we include 27 cents for congestion, 18 cents for accident, 15 cents for local air pollution, 21 cents for oil dependence and 7 cents for global climate change. 


\section{References}

American Petroleum Institute, 2007. Gasoline Taxes. http://www.api.org/statistics/ fueltaxes/upload/March_2007_gasoline_and_diesel_summary pages-2.pdf.

American Petroleum Institute, 2007. Notes to State Motor Fuel Excise and Other Tax Rates. http://www.api.org/policy/tax/stateexcise/upload/March 2007 Notes.pdf.

California Department of Transportation, Division of Transportation System, 2007. California Motor Vehicle Stock, Travel and Fuel Forecast. http://www.dot.ca.gov/hq/tsip/otfa/mtab/MVSTAFF/MVSTAFF06. pdf (appendix E, table 6 and table 8$)$.

CBS News, February 14, 2005. States Mull Taxing Drivers By Mile. CBSNews.com.

California State Board of Equilization, Special Taxes Department Fuel Taxes Division. CA Net Taxable Gasoline Gallons (Including Aviation Gasoline). http://www.boe.ca.gov/sptaxprog/spftrpts.htm.

Chouindard, H., Perloff, J., 2003. Incidence of Federal and State Gasoline Taxes. Economics Letters, 83, 55-60.

Dahl, C., Sterner, T., 1991. Analyzing Gasoline Demand Elasticities: A Survey. Energy Economics, 3(13), 203-210.

Dahl, C. A., 1979. Consumer Adjustment to a Gasoline Tax. The Review of Economics and Statistics, 6(3), 427-432. 
Davis, L.W., Kilian, L., 2009. Estimating the Effect of a Gasoline Tax on Carbon Emissions. National Bureau of Economic Research Working Paper \#14685.

Deaton, A., 1981. Optimal Taxes and the Structure of Preferences. Econometrica, 49, $1245-1260$.

Edlin, A. S., Mandic, P. K., 2006. The Accident Externality from Driving. Journal of Political Economy, 114.5, 931-955.

Energy Information Administration, 2008. California Weekly Retail Prices. http://www.eia.doe.gov/oil gas/petroleum/data publications/wrgp/mogas history. $\underline{\mathrm{html}}$.

Engle, R.F., Granger C.W.J., 1987. Cointegration and Error Correction: Representation, Estimation, and Testing. Econometrica, 55, 251-276.

Environmental Protection Agency [EPA], 2009. Climate Change. Cited 31 March 2009. URL: http://www.epa.gov/climatechange/basicinfo.html

Fullerton, D., West, S., 2003. Public Finance Solutions to Vehicle Emissions Problems in $\begin{array}{llll}\text { Californa. } & \text { The Bectronic }\end{array}$ http://www.bepress.com/fullertonwestGoodwin, P., 1992. A review of new demand elasticities with special reference to short and long-run effects of price changes. Journal of Transport Economics and Policy, 26, 155-163. 
Goodwin, P., Dargay, J., \& Hanly, M., 2004. Elasticities of road traffic and fuel consumption with respect to price and income: a review. Transport Reviews ,24 (3), 275-292.

Graham, D., Glaister, S., 2002. The demand for automobile fuel: a survey of elasticities. Journal of Transport Economics and Policy, 36, 1-26.

Graham, D., Glaister, S., 2004. Road traffic demand: a review. Transport Review, 24, 261-274.

Hall, J.V., Winer, A.M., Kleinman, M.T., Lurmann, F.W., Brajer, V., \& Colome, S.D., 1992. Valuing the health benefits of clean air. Science, 255, 812-817.

Hanly, M., Dargay, J., Goodwin, P., 2002. Review of Income and Price Elasticities in the Demand for Road Traffic. Department for Transport, London.

Haughton, J., Sarkar, S., 1996. Gasoline tax as a corrective tax: Estimates for the United States, 1970 - 1991. The Energy Journal, 172, 103-126.

Harmon Press Release March 9, 2007. Committee Chair Rejects Gas Tax Reduction for California Consumers. California State Senator Tom Harman website: http://republican.sen.ca.gov/news/35/PressRelease4630_print.asp.

Hughes, J., Knittel, C., Sperling, D., 2008. Evidence of a Shift in the Short-Run Price Elasticity of Gasoline Demand. The Energy Journal, 291, 93-114. 
Kumar, S., 2006. The Macroeconomic Effects of Oil Price Shocks: Empirical Evidence for India. Working paper as downloaded from http://papers.ssrn.com/sol3/papers.cfm?abstract_id=900285 .

Leiby, P., 2007. Estimating the Energy Security Benefits of Reduced U.S. Oil Imports. Oak Ridge National Laboratory. ORNL/TM-2007/028.Lindberg, G. 2001. Traffic Insurance and Accident Externality Charges. Journal of Transport Economics and Policy, 35, 399-416.

Mankiw, G., 2006. The Pigou Club Manifesto. HTTP://Gregmankiw.blogspot.com/2006/10/pigou-club-manifesto.htm.Mayeres, I., Ochelen, S., Proost, S.. 1996. The Marginal External Costs of Urban Transport. Transportation Research D, 1, 111-130.

Miller, T.R., Levy, D.T., Spicer, R.S., Letina, D.C. 1998. Allocating the Costs of Motor Vehicle Crashes Between Vehicle Types. Transportation Research Record, 1635, $81-87$.

The New York Times, Rutenberg, J., August 10, 2007. Bush Rejects Gas Tax as Way to Shore Up Bridges. Nytimes.com.

The New York Times, Varian, H., July 1, 2004. Parsing California Gas Prices. Nytimes.com.

Nuñez, F., Pavley, F., September 2007. AB 32: Global warming solutions act. http://www.law.stanford.edu/program/centers/enrlp/pdf/AB-32-fact-sheet.pdf. 
Parry, I., 2002. Is Gasoline Undertaxed in the United States? Resources, 148, 28 33.Parry, I. 2004. Comparing Alternative Policies to Reduce Traffic Accidents. Journal of Urban Economics, 56, 346-368.

Parry, I., Small, K., 2004. Does Britain or the United States Have the Right Gasoline Tax? Resources for the Future Discussion Paper, 02-12 rev.

Parry, I., Small, K., 2005. Does Britain or the United States have the right gasoline tax? American Economic Review, 95, 1276-1289.

Parry, I. 2005., Should Fuel Taxes Be Scrapped In Favor of Per-Mile Charges? Resources for the Future, RFF DP 06-36.

Ramsey, Frank P., 1927. A Contribution to the Theory of Taxation. Economic Journal, 37, $47-61$.

Ramsey, J., Rasche, R. and Allen, B., 1975. An Analysis of the Private and Commercial Demand for Gasoline. The Review of Economics and Statistics, 57(4),502-507.

RAND California (downloaded on 08/30/2007). Annual Congestion Cost Total Dollars. http://ca.rand.org/stats/statlist.html.

RAND California (downloaded on 01/28/2008). Total System Daily Vehicle Miles of Travel. http://ca.rand.org/stats/statlist.html.

Sandmo, A., 1976. Optimal taxation An Introduction to the Literature. Journal of Public Economics, 6, 37-54. 
The San Francisco Chronicle, Lazarus, D., April 25, 2007a. Is it Time to Raise Gas Taxes? Lexis Nexis Academic.

The San Francisco Chronicle, Lazarus, D. April 27, 2007b. Why Some Experts Want Higher Gas Tax. Lexis Nexis Academic.

The San Francisco Chronicle, Lazarus, D. April 29, 2007c. Gas Taxes Could Fuel Reforms. Lexis Nexis Academic.

SFGate.com, Yi, M. May 11, 2006. Sales Tax on Gasoline a Bonanza for State.

Sipes, K., Mendelsohn, R., 2000. The Effectiveness of Gasoline Taxation to Manage Air Pollution. Ecological Economics, 36, 299-309.

Sterner, T., 2007. Fuel Taxes: An Important Instrument for Climate Policy. Energy Policy, 35, 3194-3202.

U.S. Department of Energy/EAI, 2006. A Primer on Gasoline Prices. http://www.eia.doe.gov/bookshelf/brochures/gasolinepricesprimer/eia1)2005prim erM.html.

US Census Bureau, 2008. http://quickfacts.census.gov/qfd/states/06000.htmlUS Federal Highway Administration, Department of Transportation. 1997. 1997 Federal Highway Cost Allocation Study. Washington, DC. www.fhwa.dot.gov/policy/hcas/final/index.htm. 
US Federal Highway Administration, Department of Transportation, 2000a. Addendum to the 1997 Federal Highway Cost Allocation Study Final Report.

US Federal Highway Administration, Department of Transportation, 2000b. Highway Statistics 1999.

West, S. E., Williams III, R. C., 2007. Optimal taxation and cross-price effects on labor supply: Estimates of the optimal gas tax. Journal of Public Economics, 91, 593617. 